\title{
PLÁTICAS Y COLOQUIOS EN EL QUIJOTE*
}

JESÚS GÓMEZ

Universidad Autónoma de Madrid

\section{A Domingo}

Dentro de la historia de la novela, la importancia del diálogo es fundamental en el Quijote, si bien no ha sido analizada en la misma medida. Ya en 1910, Ortega y Gasset se refería a la novela de Cervantes como un «conjunto de diálogos» y, con posterioridad, hay un artículo de 1947 de Eleazar Huerta titulado: «El diálogo cervantino». Este artículo inicia una serie de aportaciones bibliográficas, no muy abundantes, cuyo estado de la cuestión ya he trazado ${ }^{1}$.

\begin{abstract}
* Una versión oral de estas páginas fue pronunciada como sesión del Curso de Doctorado organizado por la profesora Esther Gómez-Sierra, en la Universidad de Manchester, durante mi estancia en la misma (del 28 de abril al 2 de mayo del año 2001). Quisiera agradecer la amabilidad de la mencionada profesora al invitarme, así como las atenciones de los restantes miembros del Department of Spanish and Portuguese Studies.

1 "Don Quijote y el diálogo de la novela», Anales cervantinos, XXVIII, 1990, pp. 35-44, donde se reseñan los artículos dedicados al tema por M. Criado del Val (1955-56), C. Guillén (1979, reed. 1988), P. Jauralde (1981), E. Rivers (1984). Distinto es el planteamiento de F. LÁZARo CARRETER, "La prosa de Cervantes" (1985), reeditado con el título: «Las voces del Quijote», en forma de estudio preliminar a la edición del Instituto Cervantes, Don Quijote de la Mancha, dir. F. Rico, Barcelona, Crítica, 1998, 2 vols., pp. xxi-xxvii. Edición por la que cito de aquí en adelante, sin más que indicar entre paréntesis el número de la Parte correspondiente del Quijote, seguido del número del capítulo. En el volumen complementario de la misma, hay referencias bibliográficas al diálogo del Quijote (pp. 33 y 161), entre las que cabe citar las siguientes: J. M. PAZ GAGO, «Diálogo y dialogismo en el Quijote», en Actas del Tercer Coloquio Internacional de la Asociación de Cervantistas, Barcelona, Anthropos, 1993, pp. 221-226; C. RABELL, «Perspectivismo dialógico en el episodio de don Quijote y el vizcaíno: estado de la cuestión", Boletín de la Biblioteca Menéndez Pelayo, LXIX, 1993, pp. 87-101; A. RodríguEZ, "El arte de la conversación en el Quijote», Cervantes, XIII, 1993, pp. 89-107. Comp. J. MoN-
\end{abstract}

AC. XXXVI (2004), 247-278 
Hay que partir de la creación o de la génesis del Quijote, la cual resulta bastante azarosa, como es bien sabido. La crítica ha señalado incluso fallos constructivos, algunos de los cuales son mencionados por el propio Cervantes en la Parte segunda, como el rucio de Sancho robado sin que se advierta cuándo ni cómo. Estos posibles fallos se detectan sobre todo en la Parte primera de la novela, caracterizada por las vacilaciones cervantinas, vacilaciones que van desapareciendo en la segunda (1615), cuando algunos de sus personajes, como el bachiller Sansón Carrasco, ya han leído la primera. A partir de ese momento, como se ha apuntado en repetidas ocasiones, don Quijote y Sancho se saben personajes de ficción y, como tales, se rebelan (o se revelan) ante el autor, de manera pirandelliana y unamunesca.

En la visión que Cervantes aplica al Quijote, es básica la distancia del narrador con respecto al mundo narrativo que crea no como padre del mismo sino como "padrastro», por decirlo así, tal y como se indica en el Prólogo a la Primera parte. En este rasgo, y no sólo en éste, se distancia completamente el Quijote de la novela picaresca, caracterizada por su único punto de vista, lo que elimina la imparcialidad del relato tal y como aparece parodiado en el episodio de los galeotes (I, 22) y la autobiografía que Ginés de Pasamonte está escribiendo, al modo del Lazarillo y de otras novelas del género que Cervantes no cita de manera directa pero que tiene muy presentes, como el Guzmán de Alfarache ${ }^{2}$.

La distancia narrativa se refleja en diversos aspectos que dotan de libertad de movimientos a los personajes de la novela cervantina, caracterizada por la relatividad de los juicios tanto del narrador o narradores (Cide Hamete, el traductor morisco, el narrador cristiano, los Anales de la Mancha) como por las opiniones diversas de los personajes, en su perspectivismo, que mantienen puntos de vista encontrados $\mathrm{u}$ opuestos sobre la realidad, como el de don Quijote frente a Sancho ${ }^{3}$. La diversidad de opinio-

TERo REgUERA, El «Quijote» y la crítica contemporánea, Alcalá de Henares, Centro de Estudios Cervantinos, 1997, pp. 149-156.

${ }^{2}$ Véase la contraposición que establece G. Sobejano, «De Alemán a Cervantes: monólogo y diálogo", en Homenaje al Prof. Muñoz Cortés, Murcia: Universidad, 1977, vol. II, pp. 713-729; A. REY HAZAS, «El Quijote y la picaresca: la figura del hidalgo en el nacimiento de la novela moderna», Edad de Oro, XV, 1996, pp. 141-161; del mismo, sus palabras en el prólogo a la edición, con FLORENCIO SEVILLA, El ingenioso hidalgo don Quijote de la Mancha, Alcalá de Henares, Centro de Estudios Cervantinos, 1994, pp. xi-xiv y xvii-xix.

3 En El pensamiento de Cervantes (1925), ed. J. Rodríguez-Puértolas, Barcelona-Madrid, Noguer, 1988, pp. 32-33, señala A. Castro el contraste entre don Quijote/verdad poética y Sancho/verdad histórica con estas palabras: «Lo general de Cervantes se revela en el arte con que ha introducido en lo más íntimo de la vida 
nes que manifiestan los personajes explica la progresiva importancia que adquiere el diálogo, desde la primera salida, caracterizada por los soliloquios de don Quijote, hasta la relación dialógica fundamental que se establece entre don Quijote y Sancho, que se va desarrollando desde la segunda salida pero culmina, como veremos, en los preparativos de la tercera y última salida que hacen el hidalgo y su escudero, sobre la cual versa la Parte segunda de 1615.

Antes de comenzar propiamente con el estudio del diálogo quijotesco, hay que advertir sobre la diferencia básica y previa que hay entre el diálogo como género literario y el diálogo como forma de expresión (en la novela, en la poesía o en el teatro) ${ }^{4}$. El diálogo aparece utilizado en el Quijote como una forma de expresión, dentro del discurso narrativo, que sirve para objetivar, e independizar por ende, el mundo de los personajes con respecto a la figura del narrador.

En el desarrollo argumental del relato cervantino, importa poco la narración de sucesos, en ocasiones bastante secundaria, frente a los comentarios dialogados que suscitan los sucesos filtrados por la variedad de perspectivas y de registros lingüísticos que exhiben los personajes. Se trata de la tradición de la novela humorística y «polifónica» caracterizada por el plurilingüismo, en términos que M. Bajtin utiliza a partir del Quijote precisamente, aunque él lo aplica sobre todo a la novela decimonónica ${ }^{5}$.

de sus héroes el problema teórico que inquietaba a los preceptistas; el autor ha colocado a don Quijote en la vertiente poética y a Sancho en la histórica (...) Don Quijote hablará en nombre de la verdad universal y verosímil; Sancho defenderá la verdad sensible y particular. La oposición, como es natural y cervantino, no se resuelve, sino que queda patente, como problema abierto".

${ }^{4}$ Esta diferenciación se ha ido desarrollando de manera progresiva, gracias a los trabajos emprendidos por la crítica especializada, entre los cuales quisiera destacar sobre todo los de Ana Vian. Véase mi reciente estudio, con un estado bibliográfico actualizado sobre el problema: El diálogo renacentista, Madrid, Eds. del Laberinto, 2000.

${ }^{5}$ Entre los estudios de BAJTIN, véase en un plano genérico: «La palabra en la novela», Teoría y estética de la novela (1975), trad. cast., Madrid, Taurus, 1989, cap. V: "Dos líneas estilísticas en la novela europea», en el que opone la novela "centralizada» desde el punto de vista lingüístico y social (la novela "sofística», la caballeresca en verso, los libros de caballerías, etc.) a la novela caracterizada por el "plurilingüismo», que aunque se puede remontar a la Antigüedad clásica ( $E l$ Asno de oro y la novela de Petronio), aparece con «Don Quijote en los diálogos novelescos con Sancho y otros representantes de la realidad plurilingüe y grosera de la vida" (p. 199). Con este planteamiento, véase el reciente estudio de J. M. PAZ GAGO, "Dialogía», cap. 4 de su Semiótica del "Quijote», Amsterdam-Atlanta, Rodopi, 1995, pp. 143-166, que estudia las relaciones entre el diálogo de los personajes y las voces del narrador. 
El personaje se constituye como un interlocutor frente a los demás interlocutores, dentro del discurso narrativo, que expresan un mundo propio a través de su lenguaje bien diferenciado, de ahí el radical plurilingüismo que detecta Bajtin en el diálogo quijotesco, sobre todo en los enfrentamientos entre don Quijote y Sancho pero también en otros personajes. Poco o nada tiene que ver esta variedad novelesca de la forma dialogada utilizada en Don Quijote, dentro de su expresión polifónica, con el diálogo que como género literario específico se desarrolla durante el Renacimiento, en la obra de los Valdés, fray Luis de León, Villalón, Sepúlveda y Vives, por citar tan sólo algunos conspicuos representantes del mismo. En el género dialogado, los interlocutores, el tiempo y el espacio están al servicio de las ideas que, a su vez, dependen del proceso discursivo (lógico o retórico) de la argumentación.

$\mathrm{Ni}$ tan siquiera en aquellas obras dialogadas que, como el Viaje de Turquía, El Crotalón y los Coloquios de Palatino y Pinciano de Arce de Otálora, introducen de forma diferente esquemas narrativos dentro de la argumentación principal, se produce una variedad dialógica entre los respectivos puntos de vista de los personajes equiparable a la que se produce en el Quijote. Como género, el diálogo renacentista es un diálogo dogmático cuya intención fundamental es la de transmitir una doctrina. No ocurre así en la mayor parte de la novela de Cervantes, excepto en aquellos pasajes doctrinales que veremos en el análisis, ya que lo que predomina en el desarrollo narrativo del Quijote es la expresión dialógica de unos caracteres literarios, dentro de la ficción, cuyas voces se retratan como si fueran autónomas con respecto a la del autor.

Sobre el fenómeno anterior ha llamado la atención justamente Lázaro Carreter en su estudio reimpreso con el título: «Las voces del Quijote». Parafraseando también el título de un trabajo de Domingo Ynduráin, lo que se produce en la novela de Cervantes es «El descubrimento de la literatura» porque, entre otras cosas, frente al dogmatismo y al didactismo que caracteriza al diálogo como género, los diálogos del Quijote están utilizados para recrear al hilo de la narración un mundo cambiante e inseguro:

Frente a las ciencias normativas que aspiran a totalizar la comprensión del mundo mediante la formulación de unos principios definitivos, unívocos e invariables, universales, la literatura va creando un discurso específico en el que aparece la experiencia de lo inmediato, lo individual y circunstanciado y, por ello, cambiante, ambiguo; un discurso, pues, concebido como hijo del entendimiento y que se ofrece a un lector libre de todo respeto y obligación, por utilizar las palabras de 
Cervantes en el prólogo del Quijote, con todo lo que allí se contiene. Alternativa que sólo es posible cuando la literatura se define directamente como ficción ${ }^{6}$.

Cabe señalar que Cervantes, cuando escribe el prólogo del Quijote de 1605 lo hace parodiando las reglas retóricas, rompiendo con los tópicos de la captatio benevolentiae. Y, en una nueva vuelta de tuerca, introduce el diálogo con un «amigo mío, gracioso y bien entendido" al que plantea sus dudas, que el amigo (alter ego del mismo autor) va resolviendo. El prólogo-diálogo acaba de hacerse cuando el amigo acaba de hablar, como Lope cuando escribe un soneto a Violante sobre el modo de hacer un soneto. Cervantes, que era muy aficionado a la metaficción, como se sabe y es característico del arte barroco, escribe un metaprólogo que es al mismo tiempo un prólogo dialogístico.

Además, entre los preliminares poéticos, incluye Cervantes una serie de poemas burlescos que es la parodia de las habituales composiciones encomiásticas, y en ella pone los poemas en boca de personajes fabulosos extraídos de los libros de caballería (Orlando famoso, Urganda la Desconocida, Amadís, Belianís de Grecia, El caballero del Febo, Solisdán...), con lo que ya se introduce al lector abruptamente en la ficción caballeresca. El artificio se retoma para cerrar esta Primera parte, con una serie de poemas a cargo de los supuestos "académicos de Argamasilla»: El Monicongo, el Paniaguado, el Caprichoso, etc. Con lo que de nuevo da cabida Cervantes a una pluralidad de voces, aun en clave burlesca.

En los preliminares poéticos, hay un soneto dialogado entre el caballo del Cid y el rocín de don Quijote, que lleva por título precisamente: «Diálogo entre Babieca y Rocinante». Es la única ocasión en la que Cervantes utiliza el vocablo «diálogo», tanto en el Quijote como en el resto de su obra según parece ${ }^{7}$. Cervantes prefiere utilizar otros sinónimos para referirse a las conversaciones de sus personajes, como "plática(s)», "coloquio(s)» y «razonamiento(s)», en orden decreciente de preferencia. Según un cómputo aproximado e indicativo, en el Quijote aparece utilizado el primer vocablo de la serie en 90 ocasiones, el segundo en 19 y el tercero en 18.

${ }^{6}$ El descubrimiento de la literatura en el Renacimiento español, Discurso de recepción en la Real Academia Española, Madrid, 1997, p. 13.

7 Véase el clásico repertorio de C. FERNÁNDEZ GÓMEZ, Vocabulario de Cervantes, Madrid, Real Academia Española, 1962, s.v. «diálogo». Para el vocabulario del Quijote, disponemos aún con más comodidad de las concordancias posibles en el "Banco de Datos Textuales en DBT», al cuidado de Joan Torruella, en el CD adjunto a la mencionada edición del Instituto Cervantes. Para los índices de aparición de otros vocablos afines al 'diálogo', he utilizado también este mismo «Banco de Datos Textuales». 
En cambio, si hacemos un repaso de los títulos de aquellas obras pertenecientes al género dialogado, cuando aparece expreso algún vocablo relacionado con el mismo, se observa que por abrumadora mayoría hay de ellas una marcada preferencia por el vocablo «diálogo(s)», que aparece hasta en 63 ocasiones (sobre un total de 173 títulos catalogados), a los que cabría sumar las diez obras latinas que llevan también el vocablo «dialogus» o «dialogi»; en cambio tan sólo aparece "coloquio (s)» en 14 títulos y "colloquium» en 3. En términos aproximados, vale la comparación anterior como un nuevo síntoma de que Cervantes se separa de la tradición dialógica del género. Según queda apuntado, podemos observarlo en la sustitución del cultismo "diálogo" por otra palabra mucho más familiar, como es "plática», ajena al título de las obras dialogadas ${ }^{8}$.

Otro hecho constatable es que el diálogo va adquiriendo progresiva importancia en el desarrollo del Quijote. Al inicio: «En un lugar de la Mancha», aparece un narrador irónico y voluntarioso («de cuyo nombre no quiero acordarme») que domina a su antojo los hilos del relato, en tercera persona, sobre el hidalgo manchego, aunque puedan aparecer dudas ya en el "sobrenombre de 'Quijada', o 'Quesada', que en esto hay alguna diferencia en los autores que deste caso escriben» (I, 1). Pero la ambigüedad todavía no se ha instalado en el relato, entre otras cosas, porque el narrador nos retrata el carácter de su personaje en solitario.

Si comparamos el inicio del Quijote de 1605 con el inicio correspondiente del Quijote de 1615, sobresalen de inmediato las diferencias: en éste se suceden las pláticas entre el cura y el barbero que visitan a don Quijote todavía convalenciente, luego acude Sancho al que insultan la sobrina y el ama. Acto seguido, se quedan solos conversando el amo y el criado, viene después Sansón Carrasco, etc. Por el contrario, al inicio de la primera parte, con su héroe en solitario, ningún personaje dialoga. Lo que aparece en primer lugar son las cavilaciones del hidalgo cuyo discurrir reproduce el narrador («Decíase él»), cuando don Quijote piensa que va a encontrarse "por ahí con algún gigante» y se prepara mentalmente para tal acontecimiento. Es la primera vez, como señala Lázaro Carreter («Voces», p. xxvii), que «oímos su voz directamente». En el supuesto coloquio, don Quijote imagina probablemente en alta voz lo que diría el gigante: «Yo, señora, soy el gigante Caraculiambro, señor de la ínsula Malindrania, a quien

\footnotetext{
${ }^{8}$ La posible excepción de Luis Collado, Plática manual de artillería, Milán, P. Gotardo Poncio, 1592, cuyo tratado quinto es un diálogo, debe entenderse como 'práctica'.
} 
venció en singular batalla el jamás como se debe alabado caballero don Quijote de la Mancha» (I, 1).

Tiene don Quijote gran imaginación, alimentada por lectura de los libros de caballería, como es propio del «ingenioso» hidalgo, de ahí su tendencia al soliloquio en el que inventa o usurpa distintas «voces». La situación se repite al iniciarse la primera salida («iba hablando consigo mesmo y diciendo»), esta vez imagina cómo describiría el "sabio» cronista su historia: «Apenas había el rubicundo Apolo tendido por la faz de la ancha y espaciosa tierra las doradas hebras de sus hermosos cabellos» (I, 2), según la retórica del amanecer mitológico («meliflua armonía» de los «pajarillos con sus harpadas lenguas», "rosada Aurora»). Como indica F. Lázaro Carreter en el mismo pasaje antes citado, es la segunda vez que "oímos» a don Quijote.

Tras apostrofar al imaginario "coronista desta peregrina historia», imagina el hidalgo que se dirige a la «princesa Dulcinea», ya utilizando su característica fabla llena de arcaísmos como «me habedes fecho» y «la vuestra fermosura» (I, 2). Durante su primera salida, no establece don Quijote todavía un diálogo efectivo con el mundo real ${ }^{9}$. En su primer encuentro, que se produce en el capítulo segundo, cuando confunde "una venta» (así la denomina el narrador) con un castillo y a las dos «mozas del partido» que están en la puerta con dos «hermosas doncellas», se dirige a ellas con su característica fabla también: «Non fuyan las vuestras mercedes, ni teman desaguisado alguno, ca a la orden de caballería que profeso non toca ni atañe facerle a ninguno, cuanto más a tan altas doncellas como vuestras presencias demuestran» (I, 2). Es la primera vez que en la novela habla el hidalgo a un personaje real, pero las mozas evidentemente no comprenden el lenguaje que utiliza el anacrónico interlocutor («el lenguaje, no entendido de las señoras») y no le responden, tan sólo se ríen provocando la cólera inmediata de don Quijote.

El esquema de la situación anterior va a repetirse a lo largo y ancho de toda la primera salida. No se produce un diálogo efectivo y real entre don Quijote y el resto de los posibles interlocutores, que a lo sumo acceden a seguirle la corriente como hace el pica-

${ }^{9}$ Sobre la fabla quijotesca, véase el estudio de A. Rosenblant, La lengua del "Quijote», Madrid, Gredos, 1971, pp. 26 y ss., caracterizada por los siguientes arcaísmos: conservación de la f-inicial: fecho, fermosura, etc.; uso del adverbio non por no, de la conjución ca por pues, y sobre todo de «la antigua forma de segunda persona del plural con la -d- intervocálica»: habedes, mostrades; además del uso de vocablos anticuados como afincamiento, membrarse, maguer, vegada, insula, etc. Comp. H. MANCING, The Chivalric World of "Don Quijote», ColumbiaLondon, University of Missouri Press, 1982, pp. 16-22 y 28-45. 
resco ventero en el mismo capítulo segundo: «determinó de hablarle comedidamente» (I, 2). Pero siempre le engañan, como hace Juan Haldudo en el capítulo cuarto, tras azotar a Andrés y ser reprendido por el hidalgo; en este episodio, ensaya Cervantes un coloquio familiar y directo: «Llamad, señor Andrés, ahora - decía el labrador - al desfacedor de agravios: veréis cómo no desface aquéste» (I, 4). La ironía coloquial de labrador contrasta por completo con los pensamientos de don Quijote al respecto, en su nuevo soliloquio dirigido a Dulcinea, en el que presume de haber «desfecho el mayor tuerto y agravio que formó la sinrazón y cometió la crueldad» (I, 4).

El contraste entre el mundo imaginario de don Quijote y la realidad no puede ser más absoluto, por lo que se producen únicamente falsos diálogos, con malentendidos lingüísticos que no se aclaran. Por ejemplo, cuando en la venta le ofrecen "truchuelas» para comer (pescado en salazón), el hidalgo cree erróneamente que son truchas pequeñas, pero nadie le aclara el malentendido cuando el ventero le trae "una porción del mal remojado y peor cocido bacallao» (I, 2), de nuevo el resto de los personajes se limita a reírse.

En la primera salida, no hay término medio entre la locura de don Quijote y la realidad, porque al hidalgo le falta todavía un interlocutor adecuado como el que encuentra en la segunda salida, cuando le acompaña Sancho. Por eso, tras resultar apaleado el solitario hidalgo por el mozo de los mercaderes (I, 4), lo único que puede hacer es recurrir a su imaginación y buscar refugio de nuevo en su mundo caballeresco; al imaginarse Valdovinos herido y proyectar en el vecino que le recoge, de vuelta al lugar de la Mancha, la figura de su tío el Marqués de Mantua (I, 5) y, más tarde, al imaginarse como el Abencerraje capturado por Rodrigo de Narváez de acuerdo con el relato incluido en la Diana de Montemayor. El sistema puede prolongarse una y otra vez, dentro de la locura quijotesca.

En cambio, durante la segunda salida, cuando don Quijote es apaleado o maltratado, como ocurre en varias ocasiones: en la aventura de los molinos de viento (I, 8), en el apaleamiento nocturno de la venta de Palomeque (I, 17), en la descomunal batalla contra los ejércitos de ovejas y carneros (I, 18), en la aventura de los cueros de vino (I, 37), no se contrapone únicamente la locura del hidalgo frente a la realidad sino que median las advertencias previas de Sancho y, tras el final frustrante, el comentario a posteriori de las mismas. Es un hallazgo fundamental en la estructura de la novela y básico por lo que se refiere al sentido de las pláticas y diálogos entre don Quijote y Sancho. 
Podemos decirlo con las autorizadas palabras de Martín de Riquer:

La compañía de Sancho Panza da el tono inconfundible de la novela. Don Quijote tenía que hablar, que razonar, que convencer, que enseñar e incluso que discutir con un constante compañero, para que así pudiéramos calar hondo en su pensamiento y para evitar el socorrido y falso expediente de los monólogos a que Cervantes se había visto precisado a recurrir en los primeros capítulos. Sancho será en esta segunda salida el encargado de advertir a don Quijote del engaño de sus sentidos y de hacerle ver que la maravillas que su mente imagina no son tal, sino normales manifestaciones de una realidad cotidiana y vulgar (...). Pasada la aventura, cuando don Quijote ha sido despedido por las aspas del molino o apedreado por los pastores de los rebaños, aceptará la realidad a base de transmudarla al plano de la fantasía: eran de veras gigantes y ejércitos, pero los encantadores que le tienen ojeriza los han convertido en molinos y rebaños ${ }^{10}$.

De tal manera, que para convencer a su interlocutor Sancho, don Quijote recurre al expediente de los «encantadores», lo que no deja de ser una explicación lógica (si bien extraordinaria o que no se corresponde con la experiencia), al menos dentro de la locura quijotesca. El recurso, si no me equivoco, lo utilizan por primera vez el ama y la sobrina, a instancias del cura, tras el «donoso escrutinio» (I, 7). Pero el hidalgo lo aprovecha más tarde para atribuir la metamorfosis de gigantes en molinos al «sabio Frestón» (I, 8). El diálogo con Sancho le obliga a introducir cierta coherencia entre su mundo imaginario y la realidad real, por lo que la locura del hidalgo se objetiva gracias a las pláticas y coloquios. La amistad entre amo y criado va a convertirse en una de las piezas claves, si no en la más importante, de la narración dialógica o polifónica. Como señala $\mathrm{H}$. Bloom, en su difundida obra sobre El canon occidental: "No se me ocurre una amistad comparable en toda la literatura occidental, y desde luego ninguna que descanse de una manera tan exquisita en conversaciones tan hilarantes» ${ }^{11}$. Don Quijote no se vuelve a quedar solo en toda la novela prácticamente, siempre va a tener a su disposición un interlocutor privilegiado.

${ }^{10}$ Introd. a su ed., Don Quijote de la Mancha, Barcelona, Planeta, 1988, pp. liii-liv.

${ }_{11}$ El canon occidental, trad. cast., Barcelona, Anagrama, 1995, p. 143. Por su parte, señala J. B. AvALLE-ARCE, "Cervantes y el Quijote», en Historia y crítica de la literatura española, Barcelona, Crítica, 1980, vol. 2, p. 605: «Después de la creación de Sancho, don Quijote se queda absolutamente solo en dos ocasiones, nada más: durante la penitencia en Sierra Morena (I, 25) y en la cueva de Montesinos (II, 23). Esta inusitada soledad destaca más la importancia medular de ambos episodios». 
Los diálogos entre don Quijote y Sancho van adquiriendo progresiva importancia y protagonismo en el desarrollo narrativo, pero ambos interlocutores no parten de una relación de igualdad. El desnivel social entre amo y criado se pone de manifiesto en la diferencia de tratamientos, así mientras don Quijote trata al escudero de tú (ocasionalmente con vos), fórmula de confianza utilizada con los inferiores, Sancho se dirige al hidalgo con vuestra merced habitualmente ${ }^{12}$. En esto se diferencian también los coloquios y pláticas en el Quijote de los diálogos renacentistas, en los que se parte en general de una relación de igualdad entre los interlocutores, por lo que pueden expresar libremente sus opiniones.

Las jerarquía de los interlocutores en el género diálogo depende de su valor intelectual o del grado de conocimiento alcanzado en la transimisión de la doctrina, dentro del esquema predominante maestro/discípulo, antes que de las desigualdades sociales, como las de amo/criado, que son determinantes en el Quijote. Así, puede ocurrir que los interlocutores hagan uso de tú latinizante como fórmula de tratamiento, en el Diálogo de la dignidad del hombre de Pérez de Oliva, en los Coloquios matrimoniales de Luján, en el Diálogo de Mercurio y Carón de Alfonso de Valdés, en los anónimos El Crotalón y el Diálogo de las transformaciones de Pitágoras, por poner algunos ejemplos; o bien puede suceder que prefieran usar vos, como ocurre, entre otros ejemplos, en los Coloquios de Palatino y Pinciano de Arce de Otálora, en el anónimo Viaje de Turquía, en El Scholástico de Villalón, en De los nombres de Cristo de fray Luis de León. Pero, sea uno u otro el tratamiento elegido, lo comparten todos los interlocutores.

Es más raro, dentro de las obras pertenecientes al género dialogado, que exista un tratamiento desigual, como ocurre en el Diálogo entre el cazador y del pescador (1539) de Basurto y en $\mathrm{La}$ Doctrina cristiana (1552) de Andrés Flórez, por ejemplo. Lo que sucede es que el diálogo de Basurto está fuertemente condiciona-

\footnotetext{
${ }^{12}$ Como resume R. LAPESA, "Personas gramaticales y tratamientos en español», en Homenaje a Menéndez Pidal, IV. Revista de la Universidad de Madrid, XIX, 1970, p. 149: «El éxito que en el siglo XVI logró vuestra merced como fórmula de respeto contribuyó efectivamente a que vos se convirtiese en tratamiento para iguales de mucha confianza o para inferiores: en ambos casos hubo de colidir con el uso de tú». Así en el mismo Quijote, se dice de Vicente de la Rosa: "con una no vista arrogancia llamaba de vos a sus iguales y a los mismos que le conocían» (I, 51). Aunque el tratamiento de vos era para inferiores, A. RosENBLAT, La lengua del "Quijote», pp. 179-182, advierte que, en el Quijote, "aparece muchas veces entre iguales o como tratamiento caballeresco» de don Quijote a don Fernando (I, 37), de don Fernando y el Cura al Cautivo (I, 42), del Oidor al Cura», etc.
} 
do por una diferencia social manifiesta ya en el título del mismo $\mathrm{y}$, de acuerdo con ella, el cazador trata de tú al pescador que le responde con el apelativo de «señor». En el catecismo de Flórez, la diferencia de tratamiento viene condicionada por la diferencia de edad entre el maestro, que usa el tú: «Dime niño», y el catecúmeno que usa la fórmula: "vuestra reverencia». Contrasta el planteamiento con el catecismo de Juan de Valdés, donde aparece manifiesto ya desde el inicio el ámbito igualitario y amistoso del que parte el diálogo. En la Doctrina christiana, cuando Eusebio trata de «señoría» al Arzobispo, responde éste: "No cures agora de essas señorías, que pues estamos aquí solos, no quiero que me habléys vosotros con más cortesías que yo a vosotros» ${ }^{13}$. Y los tres interlocutores (Eusebio, el Arzobispo y el cura) pasan a usar el vos.

Al margen de las diferencias sociales, los diálogos entre don Quijote y Sancho son fundamentales dentro de la estructura del relato para consolidar el perspectivismo de la novela, como señala C. Guillén: «El componente de este proceso que más venía pidiendo la invención de Sancho Panza era el desarrollo del diálogo, que surge en los capítulos de la venta, se ensancha en los intercambios con Juan Haldudo y Pedro Alonso - que en algo prefigura a Sancho-, ocupa todo el escrutinio y continúa ahora». Se refiere Guillén el capítulo octavo de la primera parte, al inicio de la segunda salida cuando cabalgan juntos el escudero y su amo. Y añade Guillén: "Con Sancho el dialogismo puede ir convirtiéndose en el principio estructural constante de la novela, al que se sumarán otras no sólo personas sino mentes humanas independientes: contrastes dialécticos entre pareceres, que van superponiéndose» ${ }^{14}$.

Claro que la variedad de puntos de vista viene condicionada también por las diferencias sociales entre los interlocutores, así cuando don Quijote le permite a Sancho que se siente junto a él para comer, exclama el escudero irónicamente: «¡Gran merced!» porque se precia más de comer «en mi rincón sin melindres ni respetos» (I, 11). La diferencia de pareceres entre ambos se pone de manifiesto también frente al auditorio improvisado de sorprendidos cabreros que escuchan las pláticas entre don Quijote y Sancho: "No entendían los cabreros aquella jeringonza de escuderos y de caballeros andantes» (I, 11).

Por lo general, los dos personajes principales del Quijote observan los mismos sucesos pero los interpretan de modo que no es

${ }^{13}$ En Obras completas, I, ed. A. Alcalá, Madrid, Biblioteca Castro, 1997, p. 11.

${ }_{14}$ Don Quijote de la Mancha, edición del Instituto Cervantes, volumen complementario, p. 32 . 
coincidente, de acuerdo con su respectiva mentalidad. En el episodio de la bacía del barbero (I, 21), mientras Sancho identifica correctamente el objeto aludido, su amo cree que es el «yelmo de Mambrino». Sabemos que es el esquema habitual en el contraste de pareceres entre ambos, ya que el escudero suele representar la visión realista frente a la idealización visionaria de don Quijote, al igual que ocurre en otros episodios de esta segunda salida: molinos de viento/gigantes, rebaños de ovejas y carneros/ejércitos, cueros de vino/gigante, etc. Sin embargo, en el caso de la bacía/ yelmo, la oposición se complica cuando ambos llegan a la venta de Palomeque el Zurdo y varios cortesanos que hay en ella deciden en burla apoyar la versión del hidalgo (I, 45). Además, ante la insistencia de Sancho que va introduciendo ciertos visos de realidad en la locura de don Quijote, éste llega a reconocer la validez del perspectivismo: "eso que a ti te parece bacía de barbero me parece a mí el yelmo de Mambrino y a otro le parecerá otro» $(\mathrm{I}, 25)^{15}$.

En este mismo sentido que estamos comentando, la simplicidad de Sancho es clave para el desarrollo dialogístico del relato, así como lo es la locura de don Quijote. Cervantes o el narrador de la novela lo pone de manifiesto en varias ocasiones con sus comentarios, así cuando dos caballeros (uno de ellos llamado Vivaldo) se encuentran al Quijote, comenta el narrador que: «le tuvieron por loco"; pero advierte: "Con gran atención iban escuchando todos los demás la plática de los dos, y aun los mesmos cabreros y pastores conocieron la demasiada falta de juicio de nuestro don Quijote. Sólo Sancho Panza pensaba que cuanto su amo decía era verdad, sabiendo él quién era y habiéndole conocido desde su nacimiento» (I, 12). Me parece una observación fundamental, porque solamente Sancho entabla un verdadero diálogo con su amo, gracias a su simplicidad.

Lo mismo ocurre en el episodio de la fingida Princesa Micomicona, que solamente Sancho cree ser verdad, además de su amo claro está: "Con lo que quedó tan contento Sancho cuanto el cura admirado de su simplicidad y de ver cuán encajados tenía en la fantasía los mesmos disparates que su amo» (I, 29). Y, más tarde, se pregunta el propio narrador: "¿Quién no había de reír de los circunstantes, viendo la locura del amo y la simplicidad del criado» (I, 30). La misma relación locura/simplicidad se reconoce al

${ }^{15}$ Comenta A. REDondo, «Parodia, lenguaje y verdad en el Quijote: el episodio del yelmo de Mambrino (I, 21 y I, 44-45)», Otra manera de leer el "Quijote», Madrid, Castalia, 1997, p. 482 : «Verdad múltiple y multiplicación de perspectivas, una vez más, mediante la ruptura entre el nombre y la cosa». 
inicio del Quijote de 1615, cuando Sancho viene a visitar al hidalgo, el barbero dice: «no me maravillo tanto de la locura del caballero como de la simplicidad del escudero»(II, 2). Algo que el propio Sancho reconoce: "el vulgo tiene a vuestra merced por grandísimo loco, y a mí por no menos mentecato» (II, 2).

Las aventuras quijotescas, a partir de la segunda salida, estriban más en el comentario dialogado de las mismas por el caballero y su escudero, que en la escueta narración de los hechos acaecidos. Hay capítulos del Quijote enteramente dialogados, lo que se refleja en el título de algunos de ellos. Así, en la primera parte: «Donde se cuentan las razones que pasó Sancho Panza con su señor don Quijote» (I, 18); «De las discretas razones que Sancho pasaba con su amo» (I, 19); "De los sabrosos razonamientos que pasaron entre don Quijote y Sancho Panza» (I, 31); «Donde se trata del discreto coloquio que Sancho Panza tuvo con su señor don Quijote» (I, 49). El esquema se mantiene en la Parte segunda, como veremos ${ }^{16}$.

El perspectivismo que condiciona el diálogo entre don Quijote y Sancho no obsta para que sus respectivos papeles sean intercambiables, hasta cierto punto. Cuando Sancho debe explicar a Maritornes las pasadas aventuras y la profesión de su amo ("caballero aventurero»), lo hace asumiento el papel quijotesco a su manera: «Pues sabed, hermana mía, que caballero aventurero es una cosa que en dos palabras se ve apaleado y emperador» (I, 16). En este nuevo diálogo, Sancho hace de don Quijote, y Maritornes hace de Sancho.

Como ha sido observado por parte de la crítica, el proceso de quijotización de Sancho es imparable a lo largo de toda la nove$\mathrm{la}^{17}$. La caracterización dialógica del escudero también evoluciona, como lo hace el personaje. En la misma venta de Palomeque, cuando Sancho convencido todavía de las virtudes del bálsamo de Fierabrás, tiene que pedirle al cuadrillero los ingredientes para que su amo lo confeccione, lo hace asumiendo la fabla quijotesca:

\footnotetext{
${ }^{16}$ Comentanto el capítulo II, 28 (Don Quijote de la Mancha, edición del Instituto Cervantes, volumen complementario, p. 160), observa P. JAURALDE: «El capítulo es fundamentalmente un diálogo entre don Quijote y Sancho, como el I, 10; 15; el comienzo del I, 17 y 18; buena parte del I, 21 y 25, el I, 31; II, 7, 8 y 9, etc. (...) El narrador aparece muy poco, para presentar, al comienzo, y cerrar, a su término, la escena».

${ }_{17}$ Recuerda J. B. Avalle-Arce, Don Quijote como forma de vida, Madrid, Fundación Juan March/Ed. Castalia, 1976, p. 286: «Don Quijote y Sancho Panza se hacen en los diálogos de verdadera paz y amistad - con algún quebranto, como ocurre en las más unidas familias-, al punto que Salvador de Madariaga pudo hablar de la quijotización de Sancho Panza y de la sanchificación de don Quijote (Guía del lector del "Quijote», 1926)».
} 
«hacednos merced y beneficio de darnos un poco de romero, aceite, sal y vino, que es menester para curar uno de los mejores caballeros andantes que hay en la tierra, el cual yace en aquella cama malferido por las manos del encantado moro que está en la venta» (I, 17).

Al contrario, don Quijote se va haciendo más sensato, en la medida que Sancho aprende a engañarle. En este proceso, marca un punto de inflexión la aventura de los batanes (I, 20). Esta vez no es don Quijote quien proyecta directamente su locura para distorsionar la realidad, sino que es la oscuridad la que causa la confusión del hidalgo, que atribuye el ruido a otra cosa, lo mismo que le sucede al escudero. Cuando don Quijote insiste en llevar a cabo durante la misma noche la aventura, el atemorizado Sancho le engaña atando los pies de Rocinante y atribuyendo la inmovilidad del rocín a un designio divino: «el cielo, conmmovido de mis lágrimas y plegarias, ha ordenado que no se pueda mover Rocinante» (I, 20). Sancho va aprendiendo el sistema de su amo y lo utiliza, dentro de su propia simplicidad.

Cuando Sancho engaña de nuevo a don Quijote, en el episodio de la embajada a Dulcinea, haciéndole creer que la ha visto, la rústica imaginación del escudero es incapaz de remontar el vuelo hasta las alturas del de su amo. Éste le pregunta si Dulcinea estaba "ensartando perlas o bordando alguna empresa», responde Sancho que "ahechando dos hanegas de trigo en un corral de su casa»; y cuando don Quijote se refiere a su "fragancia aromática», Sancho replica "que sentí un olorcillo algo hombruno» (I, 31).

No es casualidad que, tras engañar Sancho a don Quijote en la aventura de los batanes, aparezca la primera burla del escudero que provoca la inmediata cólera del amo. Con la llegada del alba, ambos ven que el ruido lo producían «seis mazos de batán" y, después de reírse los dos, Sancho comienza a remedar paródicamente los votos caballerescos del hidalgo: "Y por aquí fue repitiendo todas o las más razones que don Quijote dijo la vez primera que oyeron los temerosos golpes» (I, 20), lo que provoca la ira de don Quijote que le apalea viendo «que Sancho hacía burla dél». Este episodio motiva las primeras reflexiones del hidalgo sobre la excesiva familiaridad que observa en sus diálogos con el escudero, recurriendo como suele hacer a los libros de caballería y señaladamente al Amadís, libro en que el escudero Gandalín muestra, según advierte don Quijote, un respeto reverencial hacia el caballero: "y se lee dél que siempre hablaba a su señor con la gorra en la mano, inclinada la cabeza y doblado el cuerpo more turquesco» (I, 20). Se debe entender la expresión en sentido meta- 
fórico, mejor que como «another lie, unethical, unscrupulous» del hidalgo ${ }^{18}$.

Concluye don Quijote sobre la manera de hablar del criado al amo: «De todo lo que he dicho has de inferir, Sancho, que es menester hacer diferencia de amo a mozo, de señor a criado, de caballero a escudero. Así que desde hoy en adelante nos hemos de tratar con más respeto» (I, 20). Este capítulo veinte es clave para la evolución dialógica entre amo y criado, porque señala el grado de confianza que han adquirido ambos, mal que le pese a don Quijote ya que el proceso resulta imparable. Con su mentalidad rústica, Sancho replica a su amo acto seguido y le demanda, en un nuevo acto que atenta contra la caballería: "cuánto ganaba un escudero de un caballero andante en aquellos tiempos, y si se concertaban por meses, o por días, como peones de albañir» (I, 20); para pasmo de su amo: «No creo yo -respondió don Quijote- que jamás los tales escuderos estuvieron a salario, sino a merced». La situación se recompone momentáneamente porque Sancho, premiado con su inclusión en el «testamento cerrado» que el hidalgo ha dejado en casa, le promete lo siguiente: «Mas bien puede estar seguro que de aquí en adelante no despliegue mis labios para hacer donaire de las cosas de vuestra merced, si no fuere para honrarle como a mi amo y señor natural» (I, 21).

La importancia que adquiere el diálogo se ve en el pasaje anterior también porque, cada vez con más frecuencia, las pláticas del Quijote versan sobre la manera de conversar que caracteriza a los interlocutores, convirtiéndose en auténticos metadiálogos, como veremos que ocurre con frecuencia en la Parte segunda. En el mismo capítulo que estamos comentando, Sancho reconoce que es incapaz de mantener su promesa: «Señor, ¿quiere vuestra merced darme licencia que departa un poco con él? Que después que

${ }^{18}$ Son palabras de H. MANCING, The Chilvalric World, p. 70. En el Amadís de Gaula, las intervenciones de Gandalín son completamente subsidiarias de las del caballero, con el que dialoga en ocasiones; por ejemplo, cuando intenta consolarse sin éxito (I, 13), le relata la embajada ante Oriana (I, 14), después de que Amadís libera al escudero de la prisión (I, 19), cuando Gandalín le acompaña en la penitencia amorosa (II, 45-48), en la batalla con el Endriago (III, 73), tras la embajada de Gandalín a la ínsula Firme (III, 78). El protagonismo dialógico de Gandalín aumenta en estos últimos episodios y, sobre todo, en su nueva embajada ante Oriana y en la intermediación con el rey Perión (IV, 89-100), hasta que es armado caballero por Amadís (IV, 109). Sin embargo, como señala don Quijote, los pasajes dialogados entre caballero y escudero son funcionales dentro de la narración $\mathrm{y}$, por lo general, breves o resumidos como cuando se hace alusión a que estaban ambos "hablando en muchas cosas» (I, 26). Pero, las conversaciones entre Amadís y Gandalín no adquieren jamás la autonomía de las pláticas entre don Quijote y Sancho. 
me puso aquel áspero mandamiento del silencio se me han podrido más de cuatro cosas en el estómago, y una sola que ahora tengo en el pico de la lengua no querría que se mal lograse» (I, 21). La observación vuelve a repetirse más adelante, subrayando la importancia de las pláticas y coloquios: «Sancho iba muerto por razonar con su amo y deseaba que él comenzase la plática, por no contravenir a lo que le tenía mandado; mas no pudiendo sufrir tanto silencio, le dijo:» (I, 25). Amenaza incluso con abandonar a su amo si no puede hablar libremente: "Si ya quisiera la suerte que los animales hablaran, como hablaban en tiempo de Guisopete, fuera menos mal, porque departiera yo con mi jumento lo que me viniera en gana y con esto pasara mi mala ventura» (I, 25).

Las tensiones entre amo y criado van acompañadas de las primeras dudas de Sancho, que encolerizan a don Quijote. Dentro de su simplicidad, se atreve el escudero a cuestionar la realidad de los libros de caballerías: «que todo debe de ser cosa de viento y mentira, y todo pastraña, o patraña, o como lo llamáremos» (I, 25). El perspectivismo que Sancho introduce mediante sus pláticas en el mundo de su amo es fundamental, porque establece con él un verdadero diálogo, aunque el relativo acuerdo entre ambos finaliza cuando el rústico se atreve a cuestionar en el mismo capítulo 25 la realidad de Dulcinea, después de que oye su nombre auténtico: «iTa, ta! —dijo Sancho-. ¿Que la hija de Lorenzo Corchuelo es la señora Dulcinea del Toboso, llamada por otro nombre Aldonza Lorenzo?» (I, 25). Con estos comentarios, ha sobrepasado de nuevo los límites: "Ya te tengo dicho antes de agora muchas veces, Sancho - dijo don Quijote-, que eres muy grande hablador» (I, 25).

Se renuevan los insultos de don Quijote a Sancho Panza cuando el escudero se atreve a sugerirle, cinco capítulos más adelante, que olvide a Dulcinea: «¿Pensáis - le dijo a cabo de rato- villano ruin (...) y que todo ha de ser errar vos y perdonaros yo? Pues no lo penséis, bellaco descomulgado» (I, 30), además de tacharle de "socarrón de lengua viperina» e incluso de "hideputa bellaco». Desde luego, no hay tal acumulación de insultos en las obras dialogadas, que giran sobre una argumentación de tipo intelectual sin que aparezcan rasgos tan emotivos como es propio de los diálogos novelescos, aun a pesar de que se pueda aducir la denominada «mímesis conversacional» ${ }^{19}$.

${ }^{19}$ Son raras aquellas obras pertenecientes al género dialogado en las que hay intercambio de insultos entre los interlocutores, nunca en la misma medida que se producen en el diálogo novelesco del Quijote. Podríamos citar por ejemplo, el Coloquio de la mosca y la hormiga de Jarava, aunque la mímesis dialógica viene 
En los capítulos finales de la Parte primera del Quijote, el diálogo cobra una importancia básica, en la escena colectiva que se desarrolla en la venta de Palomeque y, más tarde, durante el regreso al lugar de la Mancha con las sucesivas pláticas entre el cura y el canónigo, o entre el canónigo y don Quijote. En la venta de Palomeque (I, 32-46), hay dos planos en el diálogo. El marco interlocutivo sirve para introducir varios relatos, como el de la novela del "Curioso impertinente» (I, 33-35), y narraciones autobiográficas como la que cuenta el capitán cautivo (I, 38-41), de sobremesa. Ambos procedimientos aparecen tanto en la tradición narrativa, por ejemplo en la Diana que tan bien conoce Cervantes, como en los diálogos renacentistas, dentro de los cuales se introduce con cierta frecuencia diversas formas del relato corto, desde el exemplum a la novela ${ }^{20}$.

Por otra parte, se mantiene el diálogo en torno a la locura quijotesca, ya que el hidalgo y su escudero están engañados por la fábula de la Princesa Micomicona, que sirve de adelanto o de ensayo para lo que ocurre en el Quijote de 1615, cuando diversos personajes confunden al hidalgo, como hace Sancho pero también el bachiller Sansón Carrasco y, por supuesto, los Duques. Así, en la venta de Palomeque, Dorotea/Micomicona utiliza con toda perfección las convenciones de los libros de caballerías, además de imitar la fabla quijotesca con maestría, aunque Sancho barrunta algunos indicios de la burla, provocando de nuevo la ira de don Quijote.

Micomicona se dirige al hidalgo «con además señoril y acomodado al estilo de don Quijote», según comenta el propio narrador (I, 46). El diálogo caballeresco entre ambos contrasta con las dudas de Sancho sobre la verdadera identidad de la fingida princesa: «iAy, señor, señor, y cómo hay más mal en el aldegüela que se suena, con perdón sea dicho de las tocadas honradas!» Cuando don Quijote le pregunta a su escudero, responde éste: "yo tengo por cierto y averiguado que esta señora que se dice ser reina del gran reino Micomicón no le es más que mi madre, porque a ser lo que ella dice no se anduviera hocicando con alguno de los que

condicionada aquí por la tradición fabulística que ha estudiado A. VIAN en su edición del mismo: "Fábula y diálogo en el Renacimiento", Dicenda, 7, 1987, pp. 449-494. Así la mosca se refiere despectivamente a la hormiga: « $\mathrm{O} O$ miserable!» (p. 490); "¿Qué dizes, nescia?» (p. 493); «¡O, vellaca!» (p. 494).

${ }_{20}$ Véase El diálogo renacentista, pp. 145-160, además de algunos artículos específicos sobre esta cuestión, como: "Las formas del relato breve en los Coloquios de Palatino y Pinciano», Revista de Literatura, 54, 1992, pp. 75-99; «Boccaccio y Otálora en los orígenes de la novela corta española», Nueva Revista de Filología Hispánica, 46, 1998, pp. 23-46; «El marco interlocutivo de los relatos incluidos en el diálogo", Criticón, 81-82, 2001, pp. 247-69. 
están en la rueda, a vuelta de cabeza y a cada traspuesta». El contraste entre ambos planos se produce también por el uso del vocablo grosero: «hocicando» para referise a los besos que a hurtadillas se dan Dorotea y su «esposo don Fernando». Don Quijote vuelve a reaccionar coléricamente: «con voz atropellada y tartamuda lengua, lanzando vivo fuego por los ojos». De nuevo insulta a su escudero: "iOh bellaco, vilano, malmirado, descompuesto, ignorante, infacundo, deslenguado, atrevido, murmurador y maldiciente! ¿Tales palabras has osado decir en mi presencia y en la destas ínclitas señoras, y tales deshonestidades y atrevimientos osaste poner en tu confusa imaginación?»(I, 46). La ira quijoteca se dirige tanto hacia las sospechas de Sancho como hacia su modo de expresarse «infacundo, deslenguado».

Durante el regreso de don Quijote al lugar de la Mancha, «encantado" y enjaulado en la carreta de bueyes, tienen lugar los diálogos más teóricos y doctrinales que hay en la novela: el primero entre el cura y el canónigo al que encuentra de camino versa sobre los libros de caballerías, que son "perjudiciales en la república» (I, 47) y sobre la comedia nueva lopesca (I, 48). El segundo, entre el canónigo y don Quijote, vuelve a versar sobre la realidad de los libros de caballerías, aunque se trata ahora de una disputatio, o altercatio, ya que los razonamientos de ambos son opuestos (I, 49-50) ${ }^{21}$. En ambos coloquios, de carácter argumentativo, hay una cierta semejanza entre el Quijote y el género diálogo, en el que predomina la expresión de un razonamiento sobre la caracterización de los interlocutores, aunque no por ello deje de existir la mencionada ficción conversacional o dialógica ${ }^{22}$.

Junto a la argumentación teórica sobre los libros de caballerías o sobre la comedia nueva, las pláticas entre don Quijote y

${ }^{21}$ Sobre las circunstancias y la organización de la disputatio del canónigo con el hidalgo, véase A. RoldÁN PÉREz, Don Quijote, del triunfalismo a la dialéctica, Murcia, Universidad, 1974, pp. 19-57. El capítulo 50 lleva por título: «De las discretas altercaciones que don Quijote y el canónigo tuvieron".

22 G. TORRENTE BALlESTER, «El Quijote como juego», El «Quijote» como juego y otros trabajos críticos, Barcelona: Destino, 1984, p. 88, compara los diálogos del Quijote con los de León Hebreo: «La presencia de Sancho descarta el monólogo e impone el diálogo, un diálogo, si se quiere, convencional, en que cada parte discursea de lo lindo (...) El modelo indudable está en los libros dialogados al modo del León Hebreo, que tan bien conocía el autor, pero no usa el procedimiento para que los dialogantes se vayan por los cerros de Úbeda de las ideas generales más de lo necesario, sino para ceñirse, la mayor parte de las veces, a lo que la marcha de la novela propone y exige». La influencia de los Diálogos de amor de León Hebreo está demostrada, efectivamente, en La Galatea de Cervantes en el debate filosófico entre Tirsi y el desamorado Lenio. Pero los coloquios entre don Quijote y Sancho no están orientados hacia lo abstracto, sino todo lo contrario. 
Sancho mantienen la tensión narrativa. De nuevo expresa el escudero sus dudas sobre el encantamiento quijotesco, utilizando de manera paródica un razonamiento pseudo-escolástico o silogístico con que el cree haber convencido dialécticamente a su amo: «iAh -dijo Sancho- cogido le tengo!» (I, 49). La parodia del razonamiento mayéutico se repite en la Parte segunda, cuando Sancho demuestra la superioridad de los santos sobre los caballeros: "Cogido le tengo» (II, 8), vuelve a decir Sancho y su amo admite: «También confieso esta verdad» ${ }^{23}$. Pero cuando le pregunta: «¿Qué quieres que infiera, Sancho, de todo lo que has dicho?», la conclusión del escudero es disparatada: "que nos demos a ser santos y alcanzaremos más brevemente la buena fama que pretendemos» (II, 8). Sin embargo, el escudero está demostrando, de modo cómico si se quiere, su habilidad dialéctica innata que va a emplear a fondo después, por ejemplo en el episodio de la Ínsula Barataria.

La importancia progresiva que va adquiriendo el diálogo en la novela cervantina se pone de manifiesto al inicio del Quijote de 1615. Durante los preparativos de la tercera y última salida se multiplican las pláticas entre los personajes: cuando el cura y el barbero visitan al hidalgo, vuelven a discutir sobre la realidad de los libros de caballerías (II, 1); más tarde viene Sancho, al que insultan ama y sobrina, pero consigue el escudero conversar con don Quijote y le habla sobre el bachiller Sansón Carrasco, que ha leído la Parte primera impresa de la novela (II, 2); acude finalmente Sansón Carrasco, como reza el título del capítulo: «Del ridículo razonamiento que pasó entre don Quijote, Sancho y el bachiller Sansón Carrasco» (II, 3).

Son capítulos casi por entero dialogados, en los cuales lo principal son los coloquios, pláticas y razonamientos entre los personajes principales de la historia. Contrasta el movimiento conversacional de estos capítulos (II, 1-6) con el inicio del Quijote, todavía con el héroe en solitario (I, 1-6). A diferencia de lo que sucede en la Parte primera, don Quijote y Sancho aparecen perfectamente caracterizados desde el punto de vista dialógico. Se ha subrayado con razón (lo ha hecho F. Lázaro Carreter), que en los comentarios de Sansón Carrasco sobre la Primera parte impresa: «hay tal que se precia más de oíros hablar a vos que al más pintado de toda ella [historia]» (II, 3). Y, más adelante: «Vengan más quijotadas, embista don Quijote y hable Sancho Panza» (II, 4). En ambas frases, se pone de manifiesto el protagonismo que adquiere la manera de hablar de Sancho, lo cual va a ser un motivo recurrente en el Quijote de 1615.

${ }^{23}$ J. B.AvAlLE-ARCE, El "Quijote» como forma de vida, pp. 284-285, compara el interrogatorio de Sancho en I, 49 con la mayéutica socrática. 
La renovada importancia que adquiere el idiolecto de Sancho se manifiesta en el capítulo quinto, ya desde el propio título: «De la discreta y graciosa plática que pasó entre Sancho Panza y su mujer Teresa Panza». De inmediato el narrador cervantino llama la atención del lector sobre el habla de Sancho. Es un comentario sobre el propio diálogo, un metadiálogo de los que tanto abundan en la novela cervantina y, especialmente, en su Parte segunda. Dice: «Llegando a escribir el traductor desta historia este quinto capítulo, dice que le tiene por apócrifo, porque en él habla Sancho Panza con otro estilo del que se podía prometer de su corto ingenio y dice cosas tan sutiles, que no tiene por posible que él las supiese» (II, 5).

La observación del narrador cervantino es corroborada por la propia mujer de Sancho en el transcurso de la «graciosa plática» con su marido, dice ella: «después que os hicistes miembro de caballero andante, habláis de tan rodeada manera, que no hay quien os entienda" (II, 5); "Yo no os entiendo, marido -replicó Teresa-: haced lo que quisiéredes y no me quebréis más la cabeza con vuestras arengas y retóricas» (II, 5).

Sancho ha contaminado su manera de hablar con la retórica quijotesca, como hace cuando le pide al cuadrillero los ingredientes del bálsamo de Fierabrás, hasta el punto de que su mujer no le entiende. Se produce un cambio de papeles, ya que Sancho ocupa el lugar de don Quijote dialógicamente y Teresa ocupa el lugar de Sancho, hasta el punto de que el escudero reprocha en el coloquio a su mujer las mismas faltas que, en otras ocasiones, don Quijote le reprocha a Sancho. Así, cuando Teresa Panza ensarta una serie de refranes («allá van reyes do quieren leyes», con el refrán trastrocado; "la mujer honrada, la pierna quebrada»), le dice su marido: "¿Qué tiene que ver el cascajo, los broches, los refranes y el entono con lo que yo digo? Ven acá, mentecata e ignorante, que así te puedo llamar, pues no entiendes mis razones y vas huyendo de la dicha» (II, 5).

Además de reprocharle el uso impropio de los refranes, Sancho corrige el modo de hablar incorrecto de su mujer más adelante, cuando ella dice: "Y si estáis revuelto en hacer lo que decís...

- Resuelto has de decir, mujer - dijo Sancho-, y no revuelto.

- No os pongás a disputar, marido, conmigo - respondió Teresa-: yo hablo como Dios es servido y no me meto en más dibujos» (II, 5).

El perspectivismo dialógico del que ya hemos hablado y el desnivel social que caracateriza la plática entre amo y criado se traduce en lo que Amado Alonso denominó «prevaricaciones idiomáticas» de Sancho, tomando una frase de la novela cuando don 
Quijote le acusa de ser «prevaricador del buen lenguaje» (II, 19) ${ }^{24}$. Esto es lógico dada la rusticidad del escudero y su analfabetismo, que contrasta con el carácter libresco que tiene la locura de don Quijote. Así, cuando inadvertidamente le pregunta el hidalgo si ha leído en "historias» sobre otros caballeros andantes mejores que él, Sancho replica: «yo no he leído ninguna historia jamás, porque no sé leer ni escrebir» (I, 10).

Sin embargo, lo curioso es que las primeras prevaricaciones idiomáticas no las perpetra Sancho sino el cabrero llamado Pedro cuando relata la historia de Grisóstomo (I, 12). Hay una anterior de Sancho cuando confunde los «homicidios» de los que habla don Quijote con «omecillos» (es decir, rencores), pero pasa inadvertida en el coloquio ( $I, 10)$. La primera vez, por tanto, que don Quijote corrige una prevaricación es en el relato del cabrero cuando dice: "el cris del sol y de la luna», le responde: «Eclipse se llama, amigo, que no cris, el escurecerse esos dos luminares mayores»; a lo que el cabrero hace caso omiso: "no reparando en niñerías», como dice el narrador (I, 12). Pero acto seguido le corrige de nuevo don Quijote: año estil por estéril, y esta vez sí replica: "Estéril o estil, todo se sale allá», reanudando el hilo del relato. A la tercera corrección: "aunque viváis más años que sarna», afirma el cabrero erróneamente: "Decid Sarra —replicó don Quijote, no pudiendo sufrir el trocar de los vocablos del cabrero», y Pedro contesta: «Si es, señor, que me habéis de andar zahiriendo a cada paso los vocablos, no acabaremos en un año» (I, 12).

Las prevaricaciones de Sancho aparecen tan sólo ocasionalmente en la Parte primera, tienen que ver con los libros de caballería, cuando denomina: "la bebida del feo Blas» (I, 15) al mirífico bálsamo de Fierabrás, lo que también ocurre cuando confunde con un "Martino" el supuesto yelmo de Mambrino (I, 21) y a Catón «Zonzorino" por Censorino (I, 20). Pero la primera corrección de don Quijote a Sancho no llega hasta el capítulo 21 de la primera parte: "Dictado has de decir, que no litado-dijo su amo». Y Sancho la acepta de buena gana: "Sea ansí» (I, 21). Pero curiosamente don Quijote da por buena otra prevaricación de Sancho con el latín, cuando confunde redemptio por retencio, lectura errónea cuyo significado desconoce don Quijote: «No entiendo qué quiere decir retencio» (I, 25).

El recurso de las prevaricaciones se explota de manera más humorística en la carta de don Quijote para Dulcinea, cuando

${ }^{24}$ A. Alonso, "Las prevaricaciones idiomáticas de Sancho», Nueva Revista de Filología Hispánica, II, 1948, pp. 1-20; A. RosENBLAT, "Sancho, prevaricador del buen lenguaje», La lengua del «Quijote», pp. 33-35. 
Sancho no entiende la retórica de su amo: «Alta y sobajada señora», por "soberana», error que hace las delicias del cura y del barbero cuando lo oyen (I, 26). Pero las prevaricaciones idiomáticas no aparecen, de manera sistemática, hasta la Parte segunda. En su capítulo tercero, Sancho reacciona malhumoradamente cuando Sansón Carrasco le corrige: «Personajes, que no presonajes, Sancho amigo», y responde éste: "¿Otro reprobador de voquibles tenemos?» (II, 3). La desmesurada reacción del escudero anticipa el uso continuo de este recurso humorístico que se produce inmediatamente: Sancho corrige a su mujer en el capítulo quinto: «Resuelto... y no revuelto»; pero tan sólo dos capítulos más adelante es su amo quien le corrige a él: "Reducida has de decir, Sancho - dijo don Quijote-, que no relucida» (II, 7). Y Sancho esta vez afirma: "que no me emiende los vocablos», como le había advertido: «si mal no me acuerdo» (y efectivamente, tan sólo había protestado al bachiller). Y añade Sancho: «si es que entiende lo que quiero decir en ellos, y que cuando no los entienda (...), entonces podrá emendarme, que yo no soy tan fócil...». De in-mediato se produce la réplica irónica: «No te entiendo, Sancho - dijo luego don Quijote-, pues no sé qué quiere decir soy tan fócil» (II, 7).

Una vez establecido en el capítulo séptimo, las prevaricaciones puestas en boca de Sancho son un recurso dialógico constante a lo largo de la Parte segunda: sorbiese por asolviese (II, 8); cananeas por hacaneas (II, 10); friscal por fiscal (II, 19). Esta última corrección es más importante porque provoca la excusa de Sancho: «que no me he criado en la corte, ni estudiado en Salamanca, para saber si añado o quito alguna letra a mis vocablos. Sí, que, ¡válgame Dios!, no hay para qué obligar al sayagués a que hable como el toledano». Comentario que provoca la siguiente aprobación del estudiante: "porque no pueden hablar tan bien los que se crían en las Tenerías y en Zocodover como los que se pasean casi todo el día por el claustro de la Iglesia Mayor, y todos son toledanos. El lenguaje puro, el propio, el elegante y claro, está en los discretos cortesanos, aunque hayan nacido en Majalahonda». Teoría lingüística en la que se ha querido ver el ideal renacentista apoyado en la discreción, que «es la gramática del buen lenguaje, que se acompaña con el uso» (II, 19) ${ }^{25}$.

En ocasiones, hay coloquios construidos sobre la base de las prevaricaciones de Sancho. Así, cuando en la aventura del barco

${ }^{25}$ Como resume A. Rosenblat, «El ideal lingüístico de Cervantes: la discreción», La lengua del "Quijote», pp. 56-63. Damasio de Frías, como se sabe, escribe un Diálogo de la discreción en el que define y pondera las ventajas de esta virtud. 
encantado don Quijote habla de la «línea equinoccial», Sancho se refiere a "esa leña que vuestra merced dice»; y cuando cita el "cómputo de Ptolomeo», Sancho protesta: «me trae por testigo de lo que dice a una gentil persona, puto y gafo, con la añadidura de meón, o meo, o no sé cómo» (II, 29). Y durante el regreso al lugar de la Mancha, cuando los duques simulan una celada nocturna en la que apresan al hidalgo y escudero con gritos como «trogloditas, bárbaros, antropófagos, scitas, Polifemos matadores, leones carniceros»; Sancho reflexiona: «¿Nosotros tortolitas? ¿Nosotros barberos ni estropajos? ¿Nosotros perritas, a quien dicen cita, cita? No me contentan nada estos nombres» (II, 69).

Junto a las prevaricaciones idiomáticas, hay otra marca de estilo en el habla de Sancho que se desarrolla sobre todo en la Parte segunda, me refiero a la acumulación de refranes. Como se ha señalado (F. Lázaro Carreter: «Voces», p. xxxiii), la primera vez que Sancho ensarta refranes, aunque pueda parecer sorprendente, no llega hasta el capítulo 25, y don Quijote se lo hace notar: "iVálame Dios (...) y qué de necedades vas, Sancho, ensartando? ¿Qué va de lo que tratamos a los refranes que enhilas?» (I, 25). Sin embargo, es la única vez que se da este fenómeno en la Parte primera, porque en las otras ocasiones en las que Sancho cita refranes, lo hace de modo ocasional y no en sarta. Así, cuando sospecha de la fingida identidad de la princesa Micomicona: «cómo hay más mal en el aldegüela que se suena» (I, 46). Por el contrario, es el propio Quijote quien pondera el valor de los refranes, de acuerdo también con el ideal lingüístico del Renacimiento: «Paréceme, Sancho, que no hay refrán que no sea verdadero, porque todos son sentencias sacadas de la mesma experiencia» $(\mathrm{I}, 21)^{26}$.

El recurso a la sarta de refranes aparece utilizado por Teresa Panza en la «discreta y graciosa plática» con su marido, que hemos visto (I, 5). Es un acierto de la caracterización dialógica, pues Sancho adopta con su mujer tics que ha aprendido con su amo, al corregir las prevaricaciones idiomáticas y los refranes en sarta. Acto seguido, él incurre en los mismos vicios que critica, cuando

${ }^{26}$ Como se anota en la edición de Don Quijote del Instituto Cervantes (p. 223, nota), la idea vuelve a encontrarse en II, 67: "otra vez te he dicho que los refranes son sentencias breves, sacadas de la experiencia y especulación de nuestros antiguos sabios». Véase A. Rosenblat, «El refranero y el habla de Sancho», La lengua del "Quijote», pp. 35-43. La exaltación del refranero se ha explicado dentro de la corriente renacentista e incluso erasmista, como hace A. CASTRO, El pensamiento de Cervantes, pp. 182-185; recuérdese también el valor que le concede Juan de Valdés a los refranes en su Diálogo de la lengua, en consonancia con su ideal estilístico: "escribo como hablo". 
dos capítulos más adelante habla con su amo: «Teresa dice — dijo Sancho- que ate bien mi dedo con vuestra merced, y que hablen cartas y callen barbas, porque quien destaja no baraja, pues más vale una toma que dos te daré. Y yo digo que el consejo de la mujer es poco, y el que no le toma es loco» (I, 7). A lo que responde el hidalgo resignadamente: "pasad adelante, que habláis hoy de perlas».

La sarta de refranes aparece como el otro gran recurso humorístico del habla de Sancho a lo largo de la Parte segunda, así en la embajada a Dulcinea ensarta tres refranes Sancho, ante la sorpresa indignada de don Quijote: «que siempre traes tus refranes tan a pelo de lo que tratamos cuanto me dé Dios mejor ventura en lo que deseo» (II, 10). De nuevo, durante el camino hacia las bodas de Camacho: «Adónde vas a parar, Sancho, que seas maldito? - dijo don Quijote-. Que cuando comienzas a ensartar refranes y cuentos, no te puede esperar sino el mesmo Judas que te lleve» (II, 19). Más tarde le reconviene de nuevo: "Maravillárame yo, Sancho, si no mezclaras algún refrancico en tu coloquio" (II, 28). Por eso le advierte cuando manda al escudero a entrevistarse con la duquesa: "Y mira, Sancho, cómo hablas, y ten cuenta de no encajar algún refrán de los tuyos en la embajada» (II, 30).

El recurso humorístico está perfectamente dibujado pues, tras la advertencia de don Quijote y las protestas de Sancho: «¡A mí con eso!», el escudero inevitablemente ensarta dos refranes: «al buen pagador no le duelen prendas, y en casa llena presto se guisa la cena» (II, 30). Ante otra nueva sarta, la duquesa: «ni dejó de admirarse en oír las razones y refranes de Sancho» (II, 33). Más tarde, en conversación con el duque, cuando éste cita el refrán "porque del dicho al hecho hay gran trecho", Sancho replica con tres refranes en sarta, lo que provoca la reacción de don Quijote: «Maldito seas de Dios y de todos sus santos (...), y cuándo será el día, como otras muchas veces he dicho, donde yo te vea hablar sin refranes una razón corriente y concertada!» Por lo que no es de extrañar que, entre los consejos que le da el hidalgo a Sancho para el gobierno de la Ínsula Barataria: «no has de mezclar en tus pláticas la muchedumbre de refranes que sueles, que, puesto que los refranes son sentencias breves, muchas veces los traes tan por los cabellos, que más parecen disparates que sentencias» (II, 43). Pero de inmediato Sancho desoye a su amo, lo que provoca la airada reacción de éste: "iSesenta mil satanases te lleven a ti a tus refranes! Una hora ha que los estás ensartando y dándome con cada uno tragos de tormento». Y la reacción de Sancho es hilarante, en plena cólera de don Quijote: «Y ahora se me ofrecen 
cuatro que venían aquí pintiparados, o como peras en tabaque, pero no los diré, porque al buen callar llaman Sancho»(II, 43).

El recurso cómico es semejante al que se utiliza en el entremés de Los habladores, que ha sido atribuido a Cervantes, construido enteramente a base de coloquios disparatados porque los personajes no pueden evitar incurrir en el vicio que censura el título de la pieza ${ }^{27}$. Con respecto a los refranes, aparece de nuevo el recurso en el siguiente coloquio entre amo y escudero:

-No más refranes, Sancho - dijo don Quijote-, pues cualquiera de los que has dicho basta para dar a entender tu pensamiento; y muchas veces te he aconsejado que no seas tan pródigo de refranes, y que te vayas a la mano en decirlos, pero paréceme que es predicar en desierto, y castígame mi madre, y yo trómpogelas.

-Paréceme - respondió Sancho- que vuesa merced es como lo que dicen: "Dijo la sartén a la caldera: Quítate allá, ojinegra». Estáme reprehendiendo que no diga yo refranes, y ensártalos vuesa merced de dos en dos.

-Mira, Sancho - respondió don Quijote-: yo traigo los refranes a propósito, y vienen cuando los digo como anillo al dedo, pero traéslos tú tan por los cabellos, que los arrastras, y no los guías; y si no me acuerdo mal, otra vez te he dicho que los refranes son sentencias breves, sacadas de la experiencia y especulación de nuestros antiguos sabios, y el refrán que no viene a propósito antes es disparate que sentencia (II, 67).

Más adelante, le reconviene de nuevo don Quijote: «No más refranes, Sancho, por un solo Dios (...): habla a lo llano, a lo liso, a lo no intricado» (II, 71). Frase quijotesca en la que, por cierto, aparece formulado el ideal estilístico basado en la claridad y en la sencillez, que se repite en otros lugares de la novela, como en el retablo de Maese Pedro, cuando éste reclama: "Llaneza, muchacho, no te encumbres, que toda afectación es mala»(II, 26) ${ }^{28}$.

${ }^{27}$ El Entremés de los habladores se edita en la Séptima parte de las Comedias de Lope de Vega (Madrid, 1617).

${ }_{28}$ Como se anota en la edición de Don Quijote de la Mancha (Instituto Cervantes), p. 849 , la frase, "de andadura renacentista" se ha convertido "en proverbial». Entre los consejos de don Quijote a Sancho para la gobernación de la ínsula, reaparece: "que toda afectación es mala» (II, 43). Como señala A. RosenBlat, La lengua del "Quijote», p. 25: «El repudio de la afectación era sin duda un lugar común de la época, y se encuentra en todos los tratados de Retórica». Y lo compara con el ideal estilístico de Valdés en el citado Diálogo de la lengua: "sin afectación ninguna escribo como hablo"; y con el que expresa Garcilaso en el prólogo a la traducción de El Cortesano por Boscán: "Huir de la afectación sin dar consigo en la sequedad». Podemos añadir también otro diálogo, el de Damasio de Frías sobre la discreción ya mencionado, en el que el interlocutor principal (llamado Damasio precisamente) también exalta el "común hablar». Véase R. MENÉNDEZ PIDAL, «El Quijote: llaneza y claridad», La lengua castellana en el siglo XVII, Madrid, Espasa-Calpe, 1991, pp. 24-34. Los coloquios 
La certera caracterización cómica de Sancho, basada tanto en la sarta de refranes como en las prevaricaciones idiomáticas, aparece básicamente en la segunda parte del Quijote. Responde sin duda al cada vez mayor protagonismo que adquiere la figura del escudero, así cuando engaña o pretende engañar a su amo en el episodio de Dulcinea encantada (II, 9-10). Sancho conoce perfectamente la locura de su amo, con la que ya ha jugado al final de la primera parte, cuando finge haber hecho entrega de la carta de don Quijote a su dama (I, 30-31). Los papeles entre amo y criado se han invertido por completo, ya que Sancho presenta a las tres labradoras que ve a la salida del Toboso como si fueran la princesa Dulcinea y dos de sus doncellas, pero don Quijote no ve más que la realidad: "Yo no veo, Sancho - dijo don Quijote-, sino a tres labradoras sobre tres borricos» (II, 10). Sancho no se amedrenta y se dirige a ellas imitando la fabla quijotesca:

\begin{abstract}
Reina y princesa y duquesa de la hermosura, vuestra altivez y grandeza sea servida de recebir en su gracia y buen talante al cautivo caballero vuestro, que allí está hecho piedra mármol, todo turbado y sin pulsos, de verse ante vuestra magnífica presencia. Yo soy Sancho Panza, su escudero, y él es el asendereado caballero don Quijote de la Mancha, llamado por otro nombre el Caballero de la Triste Figura (II, 10).
\end{abstract}

Hasta que don Quijote se da por vencido y recurre, burlado por la astucia de su escudero, al socorrido expediente del «maligno encantador ${ }^{29}$. Por cierto, el motivo de Dulcinea encantada será recurrente en toda la Parte segunda, provocando también la burla de los duques y los azotes falsos de Sancho. Queda fuera de toda duda la discreción del escudero, aprendida a través de los coloquios con su amo, como reconoce éste: "Cada día, Sancho - dijo don Quijote-, te vas haciendo menos simple y más discreto». Y responde Sancho: «Sí que algo se me ha de pegar de la discreción de vuestra merced (...), que las tierras que de suyo son estériles y secas, estercolándolas y cultivándolas vienen a dar buenos frutos» (II, 12). Si bien don Quijote se ríe de las «afectadas razones de Sancho (...) porque de cuando en cuando hablaba de manera que le admiraba, puesto que todas o las más veces que San-

cervantinos sí heredan la tradición estilística del diálogo renacentista, al menos como ideal que exalta la naturalidad del habla coloquial.

${ }^{29}$ El papel de los encantadores para el significado global de la novela ha sido subrayado por E. AUERBACH, en su clásico estudio: "La Dulcinea encantada», Mímesis, trad. cast., México, FCE, 1975, pp. 314-340. Para una interpretación opuesta de la comicidad del episodio del engaño de Sancho (II, 10), véase LuIS Rosales, "El encantamiento», Cervantes y la libertad, Madrid, Sociedad de Estudios y Publicaciones, 1960, vol. II, pp. 136-149. 
cho quería hablar de oposición y a lo cortesano acababa su razón con despeñarse del monte de su simplicidad al profundo de su ignorancia» (II, 12).

La capacidad discursiva tanto del amo como del criado aparece ponderada en varias ocasiones. Sin embargo, la retórica quijotesca es más apta para los discursos, arengas y largos parlamentos que para el coloquio fluido, en el que sobresale la astucia innata de Sancho: "Cogido le tengo". Entre las piezas oratorias del hidalgo recordemos que en el Quijote de 1605 pronuncia el discurso sobre la Edad de Oro a los cabreros, claro: «que se pudiera muy bien escusar» (I, 11). Más tarde, el discurso sobre las armas y las letras que don Quijote pronuncia causa muy buen efecto en un auditorio cortesano y preparado para apreciar sus cualidades retóricas: "obligó a que ninguno de los que escuchándole estaban le tuviese por loco; antes, como todos los más eran caballeros, a quien son muy anejas las armas, le escuchaban de muy buena gana» (I, 37-38).

Esta misma capacidad oratoria del hidalgo aparece ponderada en la Parte segunda, en la que hay incluso un mayor predominio de la dialéctica, de los discursos y de los diálogos en general sobre la escueta narración de los hechos. En boca de don Quijote, aparecen otros discursos más o menos extensos sobre diversos temas morales y políticos, como el discurso sobre la educación de los hijos pronunciado ante el caballero del Verde Gabán (II, 16); sobre la omnipotencia del amor, en las frustradas bodas de Camacho (II, 22); sobre la necesidad de la guerra (II, 27); o los consejos que, en la línea de las colecciones de máximas y sentencias, dirige a Sancho sobre el buen gobierno de la Ínsula (II, 42). En todas estas piezas retóricas, demuestra don Quijote su buen tino y su prudencia como reconoce el propio narrador: « $i$ Quién oyera el pasado razonamiento de don Quijote que no le tuviera por persona muy cuerda y mejor intencionada? Pero, como muchas veces en el progreso desta grande historia queda dicho, solamente disparaba en tocándole en la caballería, y en los demás discursos mostraba tener claro y desenfadado entendimiento, de manera que a cada paso desacreditaban sus obras su juicio, y su juicio sus obras» (II, 43).

Por su parte, tras oír el discurso quijotesco sobre la educación de los hijos: «Admirado quedó el del Verde Gabán del razonamiento de don Quijote, y tanto, que fue perdiendo la opinión que con él tenía de ser mentecato» (II, 16). Y más tarde insiste en la misma idea que el narrador cervantino, cuando le comenta a su hijo Lorenzo: "le he visto hacer cosas del mayor loco del mundo y decir razones tan discretas, que borran y deshacen sus hechos» (II, 18). Tras el discurso sobre el amor, Sancho también se asombra: «y 
yo digo dél que cuando comienza a enhilar sentencias, y a dar consejos, no solo puede tomar un púlpito en las manos, sino dos en cada dedo, y andarse por esas plazas a ¿qué quieres boca? ¡Válate el diablo por caballero andante!»(II, 22) ${ }^{30}$. Asombro que se repite en el discurso sobre la guerra: «El diablo me lleve - dijo a esta sazón Sancho entre sí- si este mi amo no es tólogo, y si no lo es, que lo parece como un güevo a otro» (II, 27).

En cambio, Sancho destaca en los coloquios y pláticas, que han ido forjando su personalidad a lo largo del viaje compartido con el hidalgo, hasta el punto de provocar la sorpresa de éste porque se va haciendo "menos simple y más discreto", o la sorpresa negativa de su mujer Teresa cuando no le acaba de entender, porque habla de manera diferente ${ }^{31}$. Sancho aparece caracterizado como un hablador impenitente ya desde la Primera parte, cuando su amo le reconviene por la excesiva familiaridad de sus coloquios contraria a lo que se ve en los libros de caballería (I, 20). El motivo reaparece irónicamente cuando el bachiller Sansón Carrasco, que ha leído el Quijote de 1605 y acude disfrazado como caballero del Bosque, dice: «Nunca he visto yo escudero (...) que se atreva a hablar donde habla su señor; a lo menos, ahí está ese mío, que es tan grande como su padre, y no se probará que haya desplegado el labio donde yo hablo» (II, 13).

El carácter hablador de Sancho aparece destacado en varias ocasiones, ante la impaciencia de su amo: «Plega a Dios, Sancho -replicó don Quijote-, que yo te vea mudo antes que me muera» (II, 20). En otras ocasiones, con mayor tolerancia: «Hablad, hijo mío, todo aquello que os viniere al pensamiento y a la boca, que a trueco de que a vos no os duela nada, tendré yo por gusto el enfado que me dan vuestras impertinencias»(II, 28). La afición de Sancho por hablar aparece a través de la Segunda parte, en la que exhibe una gran varidad de registros dialógicos, todos ellos en clave burlesca. Así, cuando formula preguntas absurdas sobre el

${ }^{30}$ En esta ocasión, Sancho le devuelve el piropo a don Quijote ya que, con anterioridad, éste había dicho: "que en verdad que lo que has dicho de la muerte por tus rústicos términos es lo que pudiera decir un buen predicador. Dígote, Sancho, que si como tienes buen natural y discreción, pudieras tomar un púlpito en la mano y irte por ese mundo predicando lindezas» (II, 20).

${ }^{31}$ El éxito de Sancho en el diálogo reside en su naturalidad, como señala A. RosenBlat, La lengua del "Quijote», pp. 46-47: "La naturalidad es la virtud capital del diálogo: el vizcaíno habla como vizcaíno, los galeotes como galeotes, las labradoras del Toboso como aldeanas rústicas (II, 10), y Sancho como Sancho. El diálogo tiene movilidad teatral, y es uno de los mejores encantos de la obra (...) Llama la atención la riqueza exclamativa (votos, juramentos, fórmulas imprecatorias, etc., con diversas variantes eufemísticas), tan típica de nuestra lengua. Caracteriza sobre todo el habla de Sancho». 
origen de las cosas, en las que se parodia la afición por los libros como el de Polidoro Virgilio: «quién fue el primero que se rascó la cabeza", "¿quién fue el primer volteador del mundo?». Ante la ignorancia del primo humanista, Sancho responde que Lucifer, para sorpresa del primo y de don Quijote: «Esa pregunta y respuesta no es tuya, Sancho: a alguno la has oído decir». Y replica Sancho: «a buena fe que si me doy a preguntar y a responder, que no acabe de aquí a mañana» (II, 22). Las preguntas burlescas aparecen de nuevo en el episodio de Maese Pedro: "con las memorables adivinanzas del mono adivino" (II, 25) y en el de la «cabeza encantada» de Antonio Moreno (II, 62).

El protagonismo dialógico de Sancho aumenta en la visita al castillo de los duques (II, 30-59) y, sobre todo, en el episodio de la Ínsula Barataria. Desde el principio, se pone de manifiesto que los duques están muy interesados por las "gracias y donaires de Sancho». Después de que don Quijote se disculpa porque «no tuvo caballero andante en el mundo escudero más hablador ni más gracioso del que yo tengo», la duquesa ensalza sus cualidades: «De que Sancho el bueno sea gracioso lo estimo yo en mucho, porque es señal que es discreto, que las gracias y donaires, señor don Quijote, como vuesta merced bien sabe, no asientan sobre ingenios torpes; y pues el buen Sancho es gracioso y donairoso, desde aquí le confirmo por discreto»(II, 30). Son ideas recurrentes en la novela cervantina las que enlazan la discreción con la comicidad. Reaparecen, entre otros pasajes, cuando Sancho reprocha al Quijote de Avellaneda la caracterización de sus dos protagonistas principales, por oposición a la suya propia: «mi amo, valiente, discreto y enamorado, y yo, simple gracioso, y no comedor ni borracho» (II, 69).Cuando don Quijote se queda a solas con los duques, pondera su inteligencia rústica: «es uno de los más graciosos escuderos que jamás sirvió a caballero andante: tiene a veces unas simplicidades tan agudas, que el pensar si es simple o agudo causa no pequeño contento, tiene malicias que le condenan por bellaco y descuidos que le confiesan por bobo; duda de todo y créelo todo; cuando pienso que se va a despeñar de tonto, sale con unas discreciones que le levantan al cielo» (II, 32).

La conciencia de Sancho de su propia simplicidad cómica se desarrolla mucho a lo largo de su estancia en el castillo de los duques, durante la cual asume funciones bufonescas, como corresponde a la figura cómica al servicio de la nobleza cortesana. El propio Quijote le echa en cara su faceta de «truhán moderno y majadero antiguo» porque, le pregunta: "¿No adviertes, angustiado de ti, y malaventurado de mí, que si veen que tú eres un grosero villano o un mentecato gracioso, pensarán que yo soy algún 
echacuervos o algún caballero de mohatra?»(II, 31). A pesar de las promesas que hace a su amo de estar callado, Sancho es incapaz de renunciar a su protagonismo cómico: «No tema vuesa merced, señor mío, que yo me desmande ni que diga cosa que no venga muy a pelo, que no se me han olvidado los consejos que poco ha vuesa merced me dio sobre el hablar mucho o poco, o bien o mal» (II, 31).

Como advierte el narrador, es la duquesa sobre todo la que gusta de los coloquios de Sancho: «Perecía de risa la duquesa en oyendo hablar a Sancho, y en su opinión le tenía por más gracioso y por más loco que a su amo» (II, 32). Así, la duquesa reclama a Sancho para oírle hablar durante una siesta en el capítulo titulado: «De la sabrosa plática que la duquesa y sus doncellas pasaron con Sancho Panza»(II, 33).Este mismo protagonismo cómico que Sancho asume puede explicar su fantástico relato sobre el viaje aéreo en el caballo Clavileño (II, 40-41), con el que el escudero replica al viaje subterráneo igualmente fantástico que había relatado su amo sobre la cueva de Montesinos (II, 23). Además, la combinación de simplicidad y discreción que caracteriza a Sancho culmina en su gobierno de la Ínsula Barataria, durante el cual pronuncia acertadamente sentencias sobre diversos juicios, sobresaliendo de nuevo en su capacidad dialógica, ante el "pleito" del labrador con el sastre, en el de los dos ancianos y en el de la supuesta violada (II, 45); de nuevo en la ronda nocturna, ante el tejedor de «hierros de lanzas» (II, 49), más tarde en el de la horca colocada en el puente (II, 51) ${ }^{32}$. Sancho no se da cuenta del engaño de la ínsula, pero no queda ridiculizado por ello, antes al contrario. Durante el gobierno, el simple ha demostrado su discreción, como reconoce el mayordomo de los duques:

estoy admirado de ver que un hombre tan sin letras como vuesa merced, que a lo que creo no tiene ninguna, diga tales y tantas cosas llenas de sentencias y avisos, tan fuera de todo aquello que del ingenio de vuesa

\footnotetext{
${ }^{32}$ M. BAJTIN, "La palabra en la novela», p. 218, al destacar la "incomprensión polémica de lenguajes», destaca el papel de Sancho: "De ahí la diversidad de situaciones novelescas dialogísticas o de oposiciones dialogísticas: tonto y poeta, tonto y científico pedante, tonto y moralista, tonto y pope o fariseo, tonto y juez (el tonto que no entiende: ante un tribunal, en el teatro, en la reunión científica, etc.), tonto y político, etc. Esa diversidad de situaciones es utilizada ampliamente en Don Quijote (especialmente durante la gobernación de Sancho, que ofrece un terreno propicio para el desarrollo de tales situaciones dialogísticas)». Luego añade (ibid., p. 219): «El engaño gracioso del pícaro es una mentira justificada para los mentirosos; la tontería es la incomprensión justificada del engaño: éstas son las dos respuestas de la prosa al patetismo elevado y a toda seriedad y convencionalidad».
} 
merced esperaban los que nos enviaron y los que aquí venimos. Cada día se veen cosas nuevas en el mundo: las burlas se vuelven en veras y los burladores se hallan burlados (II, 49).

Don Quijote también reconoce el buen gobierno de Sancho en la carta que le envía: "Cuando esperaba oír nuevas de tus descuidos e impertinencias, Sancho amigo, las oí de tus discreciones» (II, 51). De ahí las críticas contenidas en el Quijote hacia la pintura que hay de Sancho en el Quijote apócrifo (II, 59). Son críticas que confirma de manera tajante un personaje de la propia novela de Avellaneda, don Álvaro Tarfe, cuando preguntado sobre el apócrifo Sancho, responde: «aunque tenía fama de muy gracioso, nunca le oí decir gracia que la tuviese» (II, 72). Dentro del Quijote cervantino, se establece un diálogo polémico con la tradición de los libros de caballerías y con el Quijote apócrifo de Avellaneda.

A través de la evolución dialógica de Sancho, Cervantes ha construido una figura ciertamente original con la que supera los planteamientos de otras figuras cómicas más tradicionales que derivan de la comedia, como el pastor simple del teatro primitivo y la "figura del donaire» de la comedia lopesca, ambas caracterizadas también por su origen plebeyo ${ }^{33}$. Las pláticas y coloquios de Sancho son claves en la construcción narrativa trazada por Cervantes, sobre todo por la relación dialéctica del criado con su amo.

Casi al final de la novela, cuando salen de Barcelona, reconoce don Quijote: «Muy filósofo estás, Sancho (...), y muy a lo discreto hablas. No sé quién te lo enseña» (II, 61). Una observación semejante aparece después:

${ }^{33}$ Recordemos que Avellaneda, en el prologo al Quijote apócrifo, señala la vinculación con la tradición dramática de las narraciones cervantinas, a las que califica de "comedias en prosa». En todo caso, creo que los diálogos del Quijote están menos relacionados con la tradición del diálogo renacentista que con los diálogos teatrales, en las diferentes variedades que pudo conocer Cervantes: celestinesca, pasos de Lope de Rueda, S. de Horozco, Torres Naharro, etc. Como resume E. RILEY, Introducción al "Quijote» (1986), trad. cast., Barcelona, Crítica, 1990, p. 204: «La caracterización llevada a cabo en el Quijote a través del habla sobrepasa cualquier otro logro anterior en la prosa de ficción extensa, incluida la Celestina (...). Fue el desarrollo del drama en España lo que parece haber proporcionado el ímpetu decisivo». Y cita oportunamente el artículo de A. CLOSE, "Characterization and dialogue in Cervante's 'comedias en prosa'", Modern Language Review, 76, 1981, pp. 338-356. También se ha señalado acertadamente la relación del personaje de Sancho Panza con la tradición cómica del villano, véase W. S. HENDRIX, "Sancho Panza and the Comic Types of the Sixteenth Century», Homenaje ofrecido a Menéndez Pidal, Madrid, 1925, vol. II, pp. 485-494; F. MÁroueZ VillanueVA, «La génesis literaria de Sancho Panza», Fuentes literarias cervantinas, Madrid, Gredos, 1973, pp. 20-31; M. CHEvalier, "Un aldeano llamado Sancho Panza», Folklore y literatura, Barcelona, Crítica, 1978, pp. 145-153. 
-Nunca te he oído hablar, Sancho - dijo don Quijote-, tan elegantemente como ahora; por donde vengo a conocer ser verdad el refrán que tú algunas veces sueles decir: "No con quien naces, sino con quien paces».

- ¡Ah, pesia tal —replicó Sancho-, señor nuestro amo! No soy yo ahora el que ensarta refranes, que también a vuestra merced se le caen de la boca de dos en dos mejor que a mí, sino que debe de haber entre los míos y los suyos esta diferencia, que los de vuestra merced vendrán a tiempo y los míos a deshora; pero, en efecto, todos son refranes (II, 68).

La evolución dialógica a través del carácter de los personajes, en la novela de Cervantes, es por completo diferente al desarrollo argumentativo que se produce en los diálogos renacentistas; en ninguno de los cuales, salvo quizá en casos aislados o excepcionales, hay tal riqueza de situaciones dialógicas, de comentarios referidos a las propios coloquios y pláticas: desde el parlamento retórico u oratorio hasta el intercambio coloquial de réplicas, según los diferentes registros linguísticos y sociales empleados, desde el habla cortesana de los discretos hasta el lenguaje popular o rústico.

Se observa también en las pláticas y coloquios del Quijote, especialmente cuando dialoga Sancho con el hidalgo, toda una serie de comentarios sobre la propia conversación. Estos metadiálogos, como podríamos denominarlos, constituyen una verdadera antología de consejos sobre el decoro que deben observar los personajes en su manera de hablar. Forman parte de una preferencia general, típica del Barroco, por el arte reflexivo que se hace evidente ya en el metaprólogo de 1605. El fenómeno se produce asimismo en la dramaturgia cervantina, como se ha estudiado, por la frecuencia con que utiliza Cervantes el procedimiento del «teatro dentro del teatro» ${ }^{34}$. En el Quijote, también hay observaciones metaliterarias y metanovelescas, como ocurre en el «donoso escrutinio" de la biblioteca del hidalgo (I, 6), y en las conversaciones del canónigo que versan sobre teoría literaria (I, 47-50). Dentro de esta corriente, cabe situar el metadiálogo que progresivamente aumenta, en la medida en que los personajes quijotescos se van caracterizando por su manera de hablar.

${ }^{34}$ Aparece el recurso utilizado en tres de sus Ocho comedias (1615): Los baños de Argel, La entretenida y Pedro de Urdemalas, además del entremés de El retablo de las maravillas. Para una bibliografía actualizada del recurso cervantino, véase mi artículo: "Alusiones metateatrales en las comedias de Lope de Vega», Boletín de la Real Academia Española, LXXIX, 1999, pp. 221-247. 